\title{
Coronavirus: UK screens direct flights from Wuhan after US case
}

\author{
Elisabeth Mahase
}

The BMJ

The government has announced that health teams in the UK will meet each direct flight aircraft from Wuhan, China, to check for symptoms of novel coronavirus (2019-nCoV) and to provide information in English, Mandarin, and Cantonese to all passengers about symptoms and what to do if they become ill.

A joint statement released on 22 January by the Department of Health and Social Care and Public Health England said that the risk level had been raised from "very low" to "low" because of "current evidence on the likelihood of cases being imported into this country."

But it said that no confirmed cases of the infection had currently been found in the UK and that a prototype specific laboratory test for diagnosing 2019-nCoV had now been developed.

The update comes a day after the first novel coronavirus case was detected in the US. Reports say that a man from Washington state has been put in isolation after returning home from a trip to Wuhan on 15 January. ${ }^{1}$ The first reports of the coronavirus-known then as pneumonia with unknown cause-came from Wuhan City, Hubei Province of China, on 31 December 2019. ${ }^{2}$

\section{Diagnostic kits}

On 11 and 12 January the World Health Organization received further information from the National Health Commission China that the outbreak was associated with exposures in one seafood market in Wuhan City. Chinese authorities then identified the mystery disease as a new type of coronavirus and shared its genetic sequence for countries to use in developing specific diagnostic kits.

While 440 cases (including nine deaths) had been confirmed as of 21 January, the MRC Centre for Global Infectious Disease Analysis at Imperial College London has estimated that 4000 people in Wuhan City had an onset of symptoms caused by the novel disease (uncertainty range 1000 to 9700 ) by 18 January. ${ }^{3}$

As of 22 January, seven cases have been confirmed outside China in travellers from Wuhan: three in Thailand, one in Japan, one in South Korea, one in Taiwan, and one in the US. Chinese authorities have also confirmed evidence of human-to-human transmission, as well as 15 cases in healthcare workers, the MRC Centre said.
Three direct flights arrive at London's Heathrow Airport from Wuhan each week. An isolated area of Heathrow Terminal 4 will receive these aircrafts, said the Department of Health and Social Care. The government added that the enhanced monitoring would be "kept under continuous review and expanded to other Chinese departure points if necessary."

But Neil Ferguson, director of the MRC Centre, said that flight screening was "not a panacea." Speaking at a Science Media Centre briefing on novel coronavirus on 22 January, he said, "This measure will only identify people who have symptoms as they come off the plane. If someone was infected two days before they travelled, they will arrive without any symptoms at all.

"It's essential that the entire health system is alert to the possibility that there will be cases here. If someone with the relevant moderately respiratory symptoms reports to their GP or hospital with the corresponding travel history, Public Health England will be alerted and appropriate action will be taken."

Nick Phin, Public Health England's deputy director for the National Infection Service, commented, "This is a new and rapidly evolving situation where information on cases and the virus is being gathered and assessed daily. Based on the available evidence, the current risk to the UK is considered low. We are working with the WHO and other international partners, have issued advice to the NHS, and are keeping the situation under constant review."

He added, "Individuals should seek medical attention if they develop respiratory symptoms within 14 days of visiting Wuhan, either in China or on their return to the UK. They should phone ahead before attending any health services and mention their recent travel to the city."

1 Kennedy M. 1st case of new coronavirus detected in US. NPR 2020 Jan 21. https://www. npr.org/sections/goatsandsoda/2020/01/21/798137962/china-tries-to-control-travel-inand-out-of-wuhan-to-stem-coronavirus-spread.

2 World Health Organization. Novel coronavirus (2019-nCoV) situation report 1. 21 Jan 2020. https://www.who.int/docs/default-source/coronaviruse/situation-reports/20200121sitrep-1-2019-ncov.pdf

3 Imperial College London. Report 2: Estimating the potential total number of novel coronavirus cases in Wuhan City, China. 22 Jan 2020. https://www.imperial.ac.uk/mrcglobal-infectious-disease-analysis/news--wuhan-coronavirus/.

Published by the BMJ Publishing Group Limited. For permission to use (where not already granted under a licence) please go to http://group.bmj.com/group/rights-licensing/ permissions 